The supporting information of the article entitled:

\title{
SD-91 as A Potent and Selective STAT3 Degrader Capable of Achieving Complete and Long-Lasting Tumor Regression
}

Haibin $\mathrm{Zhou}^{\dagger^{+ \pm}}$, Longchuan $\mathrm{Bai}^{\dagger^{+ \pm}}$, Renqi $\mathrm{Xu}^{\dagger^{+ \pm}}$, Donna McEachern ${ }^{\dagger^{+}}$, Krishnapriya Chinnaswamy ${ }^{\#}$, Ruiting $\mathrm{Li}^{\nabla}$, Bo Wen ${ }^{\nabla}$, Mi Wang ${ }^{\dagger+}$, Chao-Yie Yang ${ }^{\dagger+}$, Jennifer L. Meagher ${ }^{\#}$, Duxin Sun ${ }^{\nabla}$, Jeanne A. Stuckey ${ }^{\#}$, and Shaomeng Wang ${ }^{\dagger+\Phi \S *}$

${ }^{\dagger}$ Rogel Cancer Center, Departments of ${ }^{+}$Internal Medicine and ${ }^{\mathbb{I}}$ Pharmacology, Medical School, ${ }^{\S}$ Medicinal Chemistry, College of Pharmacy, ${ }^{\#}$ Life Sciences Institute, ${ }^{\nabla}$ Department of Pharmaceutical Sciences, College of Pharmacy, University of Michigan, Ann Arbor, Michigan 48109, United States

\section{Contents of Supporting Information:}

Figure S1. Stability test of SD-36 in cell culture media with/without cells: S2

Chemistry Methods: S3-S5

Biochemistry and Biology Assay Methods: S7-S10

${ }^{1} \mathrm{H}$ NMR and UPLC-MS analysis for SD-91: S11-S13 


\section{Supplementary Figures}

\begin{tabular}{|c|c|c|c|c|}
\hline & \multicolumn{2}{|c|}{ Cell culture media only } & \multicolumn{2}{c|}{ Cell culture media with cell } \\
\hline Time $(\mathrm{h})$ & SD-36 & SD-91 & SD-36 & SD-91 \\
\hline $\mathbf{0}$ & 100.00 & 1.84 & 100.00 & 0.89 \\
\hline $\mathbf{0 . 5}$ & 78.38 & 7.26 & 58.55 & 6.06 \\
\hline $\mathbf{1}$ & 60.04 & 10.81 & 44.06 & 9.92 \\
\hline $\mathbf{2}$ & 53.76 & 46.54 & 36.87 & 17.73 \\
\hline $\mathbf{4}$ & 35.11 & 64.71 & 30.22 & 35.21 \\
\hline $\mathbf{8}$ & 11.71 & 96.48 & 8.06 & 40.17 \\
\hline $\mathbf{2 4}$ & 1.08 & 100.00 & 0.79 & 100.00 \\
\hline
\end{tabular}

Stability of SD-36 in cell culture media only

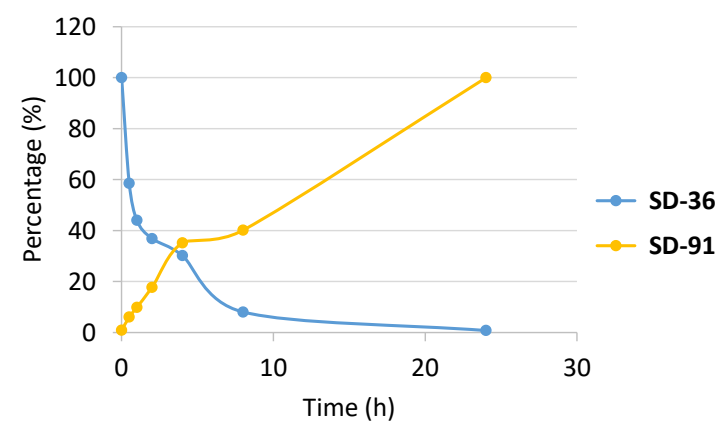

Stability of SD-36 in cell culture media with cell

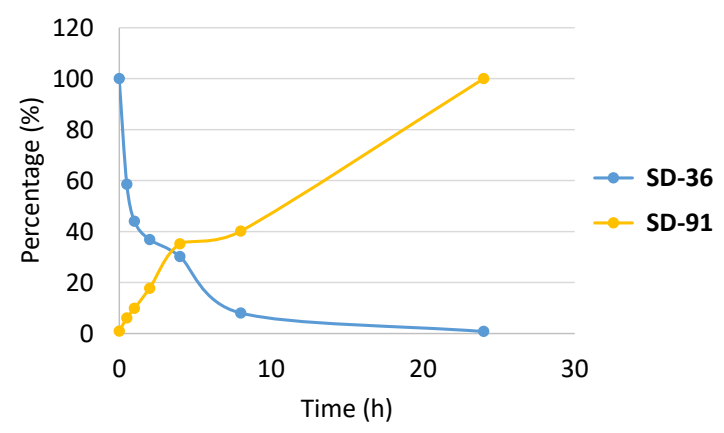

Supporting Information, Figure S1. Stability test of SD-36 in cell culture media with/without cells. Percentages of the indicated compounds at the indicated time points after incubation of SD-36 in cell culture media only and cell culture media with cells. 


\section{Chemistry Methods}

General Information. The commercial reagents and solvents were used as supplied without further purification and the reactions were performed under an $\mathrm{N}_{2}$ atmosphere. The final product was purified by reverse phase HPLC (RP-HPLC) with water (0.1\% of TFA) and $\mathrm{CH}_{3} \mathrm{CN}(0.1 \%$ of TFA) as eluents and Waters ACQUITY UPLC was used to determine the purity of $>95 \%$ pure for final compound. Proton nuclear magnetic resonance ( ${ }^{1} \mathrm{H}$ NMR) and carbon nuclear magnetic resonance $\left({ }^{13} \mathrm{C}\right.$ NMR) spectroscopy were performed on Bruker Advance 400 NMR spectrometers.
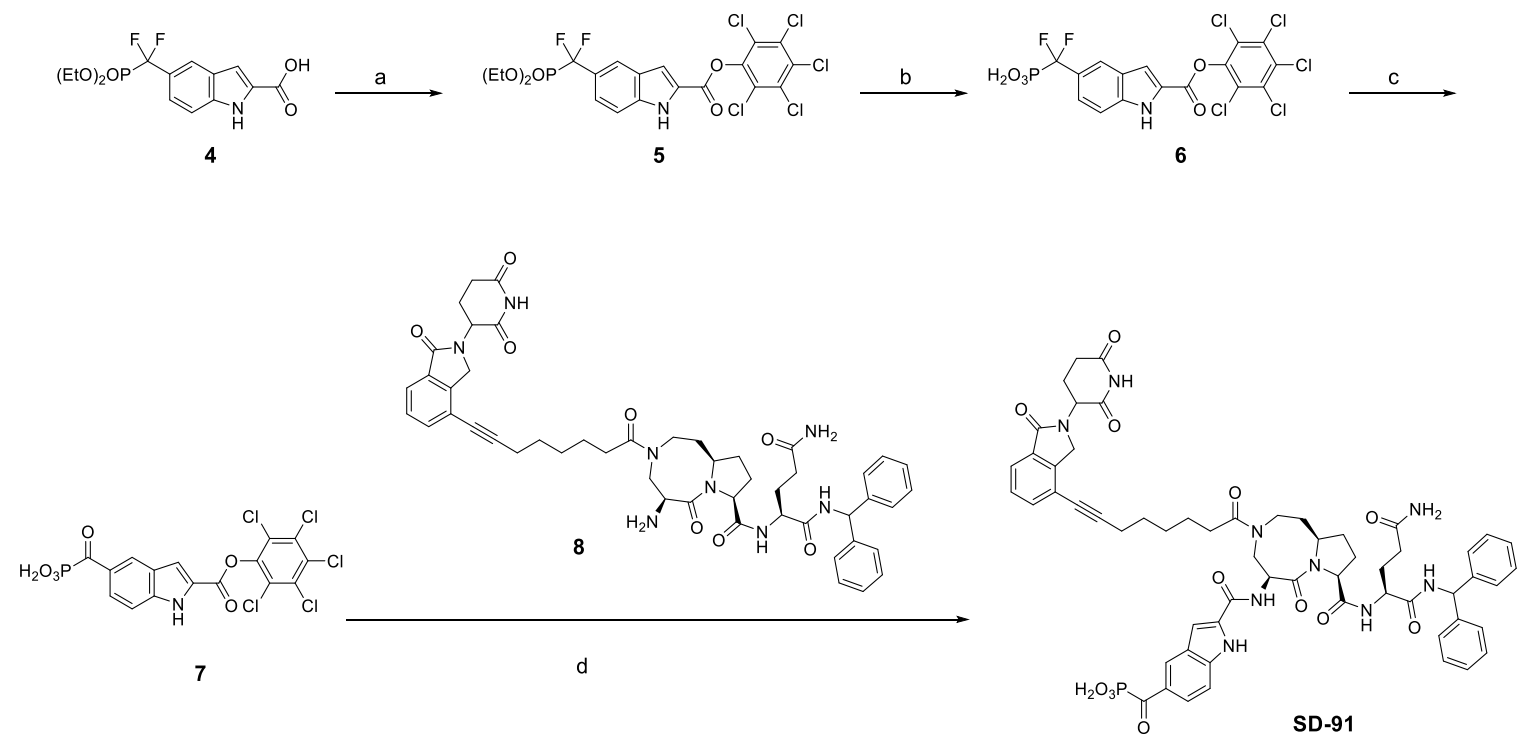

(2-((perchlorophenoxy)carbonyl)-1H-indole-5-carbonyl)phosphonic acid (7). A solution of 4 (265 mg, $0.76 \mathrm{mmol}, 1$ equiv.), pentachlorophenol (223 mg, $0.84 \mathrm{mmol}, 1.1$ equiv.), DCC (204 $\mathrm{mg}, 0.99 \mathrm{mmol}, 1.3$ equiv.), and DMAP ( $9.3 \mathrm{mg}, 0.64 \mathrm{mmol}, 0.1$ equiv.) in $3 \mathrm{~mL}$ of DMF was stirred at room temperature for $24 \mathrm{~h}$. The mixture was directly purified by HPLC to yield compound 5 (354 mg, yield: 78\%). UPLC-MS (ESI-MS) $m / z$ : calculated for $\mathrm{C}_{20} \mathrm{H}_{15} \mathrm{Cl}_{5} \mathrm{~F}_{2} \mathrm{NO}_{5} \mathrm{P}^{+}$ 593.92, found $[\mathrm{M}+\mathrm{H}]^{+}$597.85. To a round bottom flask was added 5 (354 mg, $0.59 \mathrm{mmol}, 1.0$ 
equiv) and $\mathrm{CH}_{2} \mathrm{Cl}_{2}(10 \mathrm{~mL})$. The solution was cooled to $0{ }^{\circ} \mathrm{C}$ before adding $\mathrm{CF}_{3} \mathrm{CON}(\mathrm{TMS})_{2}$ (611 mg, $2.37 \mathrm{mmol}, 4.0$ equiv) and 1M of TMS-I in DCM (1.19 mL, $1.19 \mathrm{mmol}, 2.0$ equiv). The reaction mixture was allowed to stir at $0{ }^{\circ} \mathrm{C}$ until the starting material disappear and the solvent was removed under vacuum at $0{ }^{\circ} \mathrm{C}$. The residue was dissolved in a mixture solvent of $\mathrm{CH}_{3} \mathrm{CN}$ and water, and purified by HPLC to yield 6 (254 mg, yield: $79 \%$ ). UPLC-MS (ESI-MS) $m / z$ : calculated for $\mathrm{C}_{16} \mathrm{H}_{7} \mathrm{Cl}_{5} \mathrm{~F}_{2} \mathrm{NO}_{5} \mathrm{P}^{+}$537.86, found $[\mathrm{M}+\mathrm{H}]^{+}$541.77. TFA $(8 \mathrm{~mL})$ was added to the mixture of compound $6(450 \mathrm{mg}, 0.83 \mathrm{mmol})$ in $\mathrm{CH}_{3} \mathrm{CN}(30 \mathrm{~mL})$ and water $(45 \mathrm{~mL})$. This mixture was heated to $55-60{ }^{\circ} \mathrm{C}$ for 2 days. The resulted precipitate was collected by filtration to yield compound 7 (370 mg, 86\%). ${ }^{1} \mathrm{H}$ NMR (400 MHz, DMSO) $\delta 12.90(\mathrm{~d}, J=1.4 \mathrm{~Hz}, 1 \mathrm{H}), 9.05$ $-8.89(\mathrm{~m}, 1 \mathrm{H}), 8.10(\mathrm{dd}, J=8.9,1.5 \mathrm{~Hz}, 1 \mathrm{H}), 7.86(\mathrm{dd}, J=2.0,0.8 \mathrm{~Hz}, 1 \mathrm{H}), 7.63(\mathrm{~d}, J=8.9 \mathrm{~Hz}$, 1H). ${ }^{13} \mathrm{C}$ NMR (101 MHz, DMSO) $\delta 203.33\left(\mathrm{~d}, J_{\mathrm{P}-\mathrm{C}}=174.73\right), 157.31,143.92,141.42,131.89$, $131.63,130.42,129.83,128.45,128.00,126.41,126.09,126.06,125.97,114.49,113.75$. (2-(((5S,8S, 10aR)-8-(((S)-5-amino-1-(benzhydrylamino)-1,5-dioxopentan-2-yl)carbamoyl)-3-(8(2-(2,6-dioxopiperidin-3-yl)-1-oxoisoindolin-4-yl)oct-7-ynoyl)-6-oxodecahydropyrrolo[1,2a][1,5]diazocin-5-yl)carbamoyl)-1H-indole-5-carbonyl)phosphonic acid (SD-91). DIEA (12 $\mu \mathrm{L}$, $0.068 \mathrm{mmol}, 3$ equiv.) was added to the mixture of compound 7 (14 $\mathrm{mg}, 0.027 \mathrm{mmol}, 1.2$ equiv.), compound 8 (20 mg, $0.023 \mathrm{mmol}, 1$ equiv.) and HOBt (6 mg, $0.045 \mathrm{mmol}, 2$ equiv.) in DMF (2 $\mathrm{mL}$ ). The resulted mixture was stirred at room temperature for 0.5 hour. Purification of this reaction mixture by HPLC gave the compound SD-91 (20 mg, 80\%). ${ }^{1} \mathrm{H}$ NMR (400 MHz, $\left.\mathrm{CD}_{3} \mathrm{CN}: \mathrm{D}_{2} \mathrm{O}=1: 1\right) \delta 8.79-8.66(\mathrm{~m}, 1 \mathrm{H}), 8.06-7.93(\mathrm{~m}, 1 \mathrm{H}), 7.80-7.43(\mathrm{~m}, 4 \mathrm{H}), 7.42-$ $7.05(\mathrm{~m}, 11 \mathrm{H}), 6.06-6.02(\mathrm{~m}, 1 \mathrm{H}), 5.14-4.89(\mathrm{~m}, 2 \mathrm{H}), 4.49-4.24(\mathrm{~m}, 4 \mathrm{H}), 3.96-3.24(\mathrm{~m}, 5 \mathrm{H})$, $2.88-2.68(\mathrm{~m}, 2 \mathrm{H}), 2.64-2.25(\mathrm{~m}, 7 \mathrm{H}), 2.22-2.00(\mathrm{~m}, 4 \mathrm{H}), 1.94-1.38(\mathrm{~m}, 11 \mathrm{H}) .{ }^{1} \mathrm{H}$ NMR (400 MHz, DMSO- $\left.d_{6}\right) \delta 12.13(\mathrm{~m}, 1 \mathrm{H}), 10.99(\mathrm{~s}, 1 \mathrm{H}), 8.92-8.66(\mathrm{~m}, 2 \mathrm{H}), 8.52-8.11(\mathrm{~m}, 2 \mathrm{H})$, 
7.98-7.95 (m, 1H), 7.76-7.67 (m, 1H), 7.66-7.59 (m, 1H), 7.57-7.45 (m, 2H), 7.44-7.11 (m, 11H), 6.79-6.72 (m, 1H), 6.13-6.09 (m, 2H), 5.23-5.06 (m, 1H), 5.03- $4.80(\mathrm{~m}, 1 \mathrm{H}), 4.56-4.14(\mathrm{~m}$, $5 \mathrm{H}), 4.10-3.17(\mathrm{~m}, 4 \mathrm{H}), 3.00-2.80(\mathrm{~m}, 1 \mathrm{H}), 2.76-2.50(\mathrm{~m}, 6 \mathrm{H}), 2.47-2.41(\mathrm{~m}, 1 \mathrm{H}), 2.25-1.37$ (m, 16H). UPLC-MS (ESI-MS) $m / z$ : calculated for $\mathrm{C}_{59} \mathrm{H}_{63} \mathrm{~N}_{9} \mathrm{O} 13 \mathrm{P}^{+} 1136.43$, found $[\mathrm{M}+\mathrm{H}]^{+}$ 1136.09.
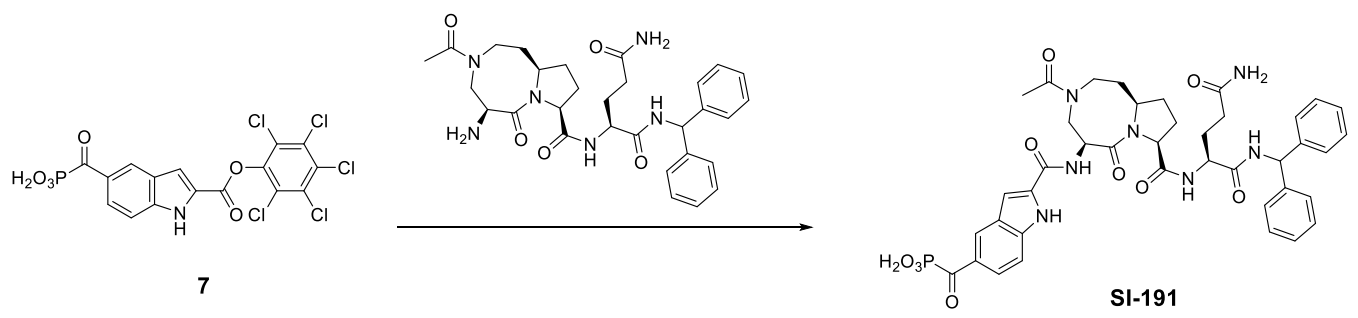

(2-(((5S,8S, 10aR)-3-acetyl-8-(((S)-5-amino-1-(benzhydrylamino)-1,5-dioxopentan-2-

yl)carbamoyl)-6-oxodecahydropyrrolo[1,2-a][1,5]diazocin-5-yl)carbamoyl)-1H-indole-5-

carbonyl)phosphonic acid (SI-191). SI-191 was prepared from 7 by a procedure similar to that used for SD-91. ${ }^{1} \mathrm{H}$ NMR $\left(400 \mathrm{MHz}, \mathrm{CD}_{3} \mathrm{CN}: \mathrm{D}_{2} \mathrm{O}=1: 1\right) \delta 8.69(\mathrm{~s}, 1 \mathrm{H}), 7.94(\mathrm{~d}, J=7.1 \mathrm{~Hz}$, $1 \mathrm{H}), 7.52-7.50(\mathrm{~m}, 1 \mathrm{H}), 7.24(\mathrm{dd}, J=25.7,6.0 \mathrm{~Hz}, 11 \mathrm{H}), 6.01(\mathrm{~s}, 1 \mathrm{H}), 5.04-4.98 \mathrm{~m}, 1 \mathrm{H}), 4.31-$ $4.23(\mathrm{~m}, 3 \mathrm{H}), 3.82-3.79(\mathrm{~m}, 1 \mathrm{H}), 3.70-3.51(\mathrm{~m}, 2 \mathrm{H}), 3.40-3.37(\mathrm{~m}, 1 \mathrm{H}), 2.27-2.21(\mathrm{~m}, 2 \mathrm{H})$, $2.12-1.82(\mathrm{~m}, 9 \mathrm{H}), 1.70-1.65$ (m, 2H). UPLC-MS (ESI-MS) $\mathrm{m} / z$ : calculated for $\mathrm{C}_{40} \mathrm{H}_{44} \mathrm{~N}_{7} \mathrm{O} 10 \mathrm{P}^{+}$814.30, found $[\mathrm{M}+\mathrm{H}]^{+} 814.52$. 


\section{Biochemistry and Biology Assay Methods}

Stability test for SD-36 and SD-91. The stability of SD-36 and SD-91 was tested in RPMI 1640 (Gibco) cell culture medium, 10\% PEG400 vehicle, $\mathrm{pH}$ buffer solution $(\mathrm{pH}=8)$ and $\mathrm{pH}$ buffer solution $(\mathrm{pH}=4)$. The drugs $(1 \mathrm{mg})$ were added to the medium or buffer solution $(1 \mathrm{~mL})$, and incubated at indicated temperature for the indicated time points. At the end of incubation, the samples were diluted with a mixture of $\mathrm{MeCN}$ and $\mathrm{H} 2 \mathrm{O}(1: 1)$ and analyzed using UPLC-MS for the quantitative analysis.

To mimic the physiological conditions, the stability of SD-36 was tested in RPMI 1640 (Gibco) cell culture medium with or without cells at $37^{\circ} \mathrm{C}$. Briefly, complete cell growth medium (RPMI 1640 plus $10 \%$ fetal bovine serum (Hyclone) with or without MOLM-16 cell $\left(5 \times 10^{\wedge} 4 / \mathrm{ml}\right)$ was maintained at $37^{\circ} \mathrm{C}$ in a humidified $5 \% \mathrm{CO} 2$ incubator overnight. Then the drugs $(10 \mu \mathrm{M})$ were added to the medium and incubated for the indicated time points. At the end of incubation, medium was collected and mixed with cold acetonitrile (Sigma) at a ratio of 1:3 (medium:ACN), vortexed for $10 \mathrm{sec}$, and then centrifugated at 15,000 rpm for $5 \mathrm{~min}$. The supernatant was collected for analysis. The supernatant $(30 \mu \mathrm{l})$ was transferred to 96 wells plates. Then $120 \mu 1$ acetonitrile containing $25 \mathrm{nM}$ internal standard CE302 was added and vortexed for $10 \mathrm{~min}$. The plates were centrifuged at 35,00 rpm for $10 \mathrm{~min}$ to precipitate protein. The clear supernatants were transferred to another injection 96-well plate and $5 \mu \mathrm{l}$ was injected into LC/MS/MS. The quantitative LC/MS/MS analysis were conducted using an Shimazu LC-20 AC UFLC system coupled to an API 4500 mass spectrometer (Applied Biosystems, MDS Sciex Toronto, Canada) equipped with an API electrospray ionization (ESI) source. Chromatographic separation achieved on Agilent Extend-C18 column $(2.1 \times 50 \mathrm{~mm}, 5 \mu \mathrm{m})$ with a gradient mobile phase consisting of $0.1 \%$ formic Acid in water (mobile phase A), and $0.1 \%$ formic Acid in Acetonitrile 
(mobile phase B) at a flow rate of $0.8 \mathrm{~mL} / \mathrm{min}$. The ion transitions are monitored at $\mathrm{m} / \mathrm{z} 1158.3$ $[\mathrm{M}+\mathrm{H}]^{+} \rightarrow 1118.2$ for SD-36 and $\mathrm{m} / \mathrm{z} 1136.4[\mathrm{M}+\mathrm{H}]^{+} \rightarrow 167.1$ for SD-91 in the positive ion mode.

Fluorescence polarization (FP) assay. The fluorescence polarization (FP) assay was performed as described previously. ${ }^{1,2}$ Briefly, STAT3 recombinant protein was incubated with tracer for $5 \mathrm{~min}$, then added to the serially diluted SD-36 or SD-91 for $1 \mathrm{~h}$. $\mathrm{IC}_{50}$ values of tracer displacement were calculated by nonlinear regression analysis using GraphPad Prism software. The $\mathrm{K}_{\mathrm{i}}$ values of competitive inhibitors were calculated as described previously.

Biolayer Interferometry (BLI) Assay. The biolayer interferometry (BLI) assay was performed as described previously. ${ }^{2}$ Briefly, purified recombinant STAT proteins were biotinylated using the EZ-Link biotinylation reagent (Thermo Fisher Scientific). Protein and biotinylation reagent were mixed with 1:1 molar ratio in PBS at $4^{\circ} \mathrm{C}$. Low biotinylation reagent concentration was applied to avoid protein over-biotinylation. These reaction mixtures were incubated at $4^{\circ} \mathrm{C}$ for 2 hours to allow completion of the reaction. Reaction mixture was then dialyzed using 10K MWCO dialysis cassettes (Thermo Fisher Scientific) to remove unreacted biotinylation reagent.

An OctetRED96 instrument from ForteBio was used for the BLI experiments. All assays were run at $30^{\circ} \mathrm{C}$ with continuous $1000 \mathrm{RPM}$ shaking. PBS with $0.1 \%$ BSA, $0.01 \%$ Tween-20 and $1 \%$ DMSO was used as the assay buffer. Biotinylated STAT proteins were tethered on Super Streptavidin (SSA) biosensors (ForteBio) by dipping sensors into $10 \mu \mathrm{g} / \mathrm{mL}$ protein solutions. Average saturation response levels of $10-15 \mathrm{~nm}$ were achieved in 15 minutes for all STAT proteins. Sensors with proteins tethered were washed in assay buffer for 10 minutes to eliminate 
nonspecifically bound protein molecules and establish stable base lines before starting associationdissociation cycles with test compound. DMSO-only references were included in all assays. Raw kinetic data collected were processed in the Data Analysis software provided by the manufacturer using double reference subtraction in which both DMSO-only reference and inactive reference were subtracted. Resulting data were analyzed based on 1:1 binding model from which $\mathrm{k}_{\text {on }}$ and $\mathrm{k}_{\text {off }}$ values were obtained and then $\mathrm{K}_{\mathrm{d}}$ values were calculated.

Western Blot analysis. Western blotting was performed as described previously. ${ }^{1,2}$ Briefly, cells were lysed in Cell Lysis Buffer (Cell Signaling Technology, \#9803), separated by SDS-PAGE NuPAGE gels (Thermo Fisher Scientific), and transferred to a Immobilon-FL PVDF membrane (MilliporeSigma). Membranes were first blocked for $1 \mathrm{~h}$ using Intercept Blocking Buffer (\#927-60010, LI-COR), then were incubated with the primary antibodies followed by IRDye® 800CW goat anti-mouse (\#926-32210, LI-COR) and IRDye® 680RD goat anti-rabbit (\#926-68071, LI-COR) secondary antibodies. Odessey CLx (LI-COR) was used to scan the images. Signal intensities were calculated using Image Studio Ver 5.2 (LI-COR). These primary antibodies were used: Stat1 (D1K9Y) Rabbit mAb (\#14994, Cell Signaling Technology), Stat2 (D9J7L) Rabbit mAb (\#72604, Cell Signaling Technology), Stat3 (D3Z2G) Rabbit mAb (\#12640, Cell Signaling Technology), Stat3 (124H6) Mouse mAb (\#9139, ,Cell Signaling Technology), Stat4 (C46B10) Rabbit mAb (\#2653, Cell Signaling Technology), Stat5 (D2O6Y) Rabbit mAb (\#94205, Cell Signaling Technology), Stat6 (D3H4) Rabbit mAb (\#5397, Cell Signaling Technology), Stat1 mouse monoclonal antibody (C-136) (sc-464, Santa Cruz Biotechnology), Stat5 (A-9) (sc-74442, Santa Cruz Biotechnology), Stat6 (D-1) (sc-374021, Santa Cruz Biotechnology), GAPDH (0411) (sc-47724, Santa Cruz Biotechnology) and GAPDH (6C5) (sc-32233, Santa Cruz Biotechnology). 
Proteomic analysis. Proteomic analysis was performed as described previously. ${ }^{2}$ Essentially, MOLM-16 cells were treated with DMSO and SD-91 for 4 hrs. At the end of treatment, cells were collected, washed with PBS, then lysed in RIPA buffer (Sigma, \#R0278). Cell lysates were proteolyzed and labeled with TMT 10-plex Isobaric Label Reagent (Thermo Fisher Scientific, \#90110) following manufacturer's protocol. Proteomic analysis was performed by the Mass Spectrometry-Based Proteomics Resource Facility of University of Michigan.

Cell Growth Assay. Cell viability analysis was performed as described previously. ${ }^{1,2}$ Briefly, cells grown in 384-well white plates (Corning Costar) were incubated with serially diluted compounds for 4 days. Cell viability was determined using the CellTiter-Glo 2.0 Luminescent Cell Viability Assay (Promega) following the manufacturer's instructions.

In Vivo PK/PD and Efficacy. In Vivo PK/PD and Efficacy experiments was performed as described previously. ${ }^{1,2}$ Female CB.17 SCID mice (Charles River Labs) were injected subcutaneously with $3 \times 10^{6}$ MOLM- 16 cells or $1 \times 10^{7}$ SU-DHL-1 cells in $5 \mathrm{mg} / \mathrm{ml}$ Matrigel (Corning). For PK/PD studies, tumor bearing mice were given a single dose of drug and euthanized with $\mathrm{CO}_{2}$ overdose at the indicated time points. Blood was immediately drawn via cardiac puncture, placed in lithium heparin tubes and centrifuged for plasma for PK analysis. Tumor tissues were harvested for Western blotting and PK analysis. For efficacy in MOLM-16 tumors, when the tumors reached an average volume of $150 \mathrm{~mm}^{3}$, mice were randomly assigned to different experimental groups for treatment. Drugs or vehicle control $(10 \%$ PEG400 $+90 \%$ PBS) were given intravenously via tail vein at the indicated dose schedule. Tumor sizes and animal weights were measured 2-3 times per week. Tumor volumes were calculated as: tumor volume $\left(\mathrm{mm}^{3}\right)=\left(\right.$ length $\times$ width $\left.{ }^{2}\right) / 2$. All in vivo studies were carried out under the animal 
protocol PRO00007499, which was approved by the Institutional Animal Care \& Use Committee (IACUC) of the University of Michigan and is in accordance with the recommendations in the Guide for the Care and Use of Laboratory Animals of the National Institutes of Health.

\section{The protocol for determining the concentration of SD-36 and SD-91 in the plasma}

and tumors. $30 \mu 1$ Plasma samples or tissue homogenate were transferred to 96 wells plates. Then $120 \mu 1$ acetonitrile containing $25 \mathrm{nM}$ internal standard CE302 was added and vortexed for $10 \mathrm{~min}$. The plates were centrifuged at $35,00 \mathrm{rpm}$ for $10 \mathrm{~min}$ to precipitate protein. The clear supernatants were transferred to another injection 96-well plate and $5 \mu 1$ was injected into LC/MS/MS. The quantitative LC/MS/MS analysis were conducted using an Shimazu LC-20 AC UFLC system coupled to an API 4500 mass spectrometer (Applied Biosystems, MDS Sciex

Toronto, Canada) equipped with an API electrospray ionization (ESI) source. Chromatographic separation achieved on Agilent Extend-C18 column $(2.1 \times 50 \mathrm{~mm}, 5 \mu \mathrm{m})$ with a gradient mobile phase consisting of $0.1 \%$ formic Acid in water (mobile phase A), and $0.1 \%$ formic Acid in Acetonitrile (mobile phase B) at a flow rate of $0.8 \mathrm{~mL} / \mathrm{min}$. The ion transitions are monitored at $\mathrm{m} / \mathrm{z} 1158.3[\mathrm{M}+\mathrm{H}]^{+} \rightarrow 1118.2$ for SD-36 and $\mathrm{m} / \mathrm{z} 1136.4[\mathrm{M}+\mathrm{H}]^{+} \rightarrow 167.1$ for SD-91.

\section{References}

1. Zhou, H.; Bai, L.; Xu, R.; Zhao, Y.; Chen, J.; McEachern, D.; Chinnaswamy, K.; Wen, B.; Dai, L.; Kumar, P.; Yang, C. Y.; Liu, Z.; Wang, M.; Liu, L.; Meagher, J. L.; Yi, H.; Sun, D.; Stuckey, J. A.; Wang, S. Structure-Based Discovery of SD-36 as a Potent, Selective, and Efficacious PROTAC Degrader of STAT3 Protein. J Med Chem 2019, 62, 11280-11300.

2. Bai, L.; Zhou, H.; Xu, R.; Zhao, Y.; Chinnaswamy, K.; McEachern, D.; Chen, J.; Yang, C. Y.; Liu, Z.; Wang, M.; Liu, L.; Jiang, H.; Wen, B.; Kumar, P.; Meagher, J. L.; Sun, D.; Stuckey, J. A.; Wang, S. A Potent and Selective Small-Molecule Degrader of STAT3 Achieves Complete Tumor Regression In Vivo. Cancer Cell 2019, 36, 498-511 e417. 
${ }^{1} \mathrm{H}$ NMR for compound SD-91 $\left(\mathrm{CD}_{3} \mathrm{CN}: \mathrm{D}_{2} \mathrm{O}=1: 1\right)$.
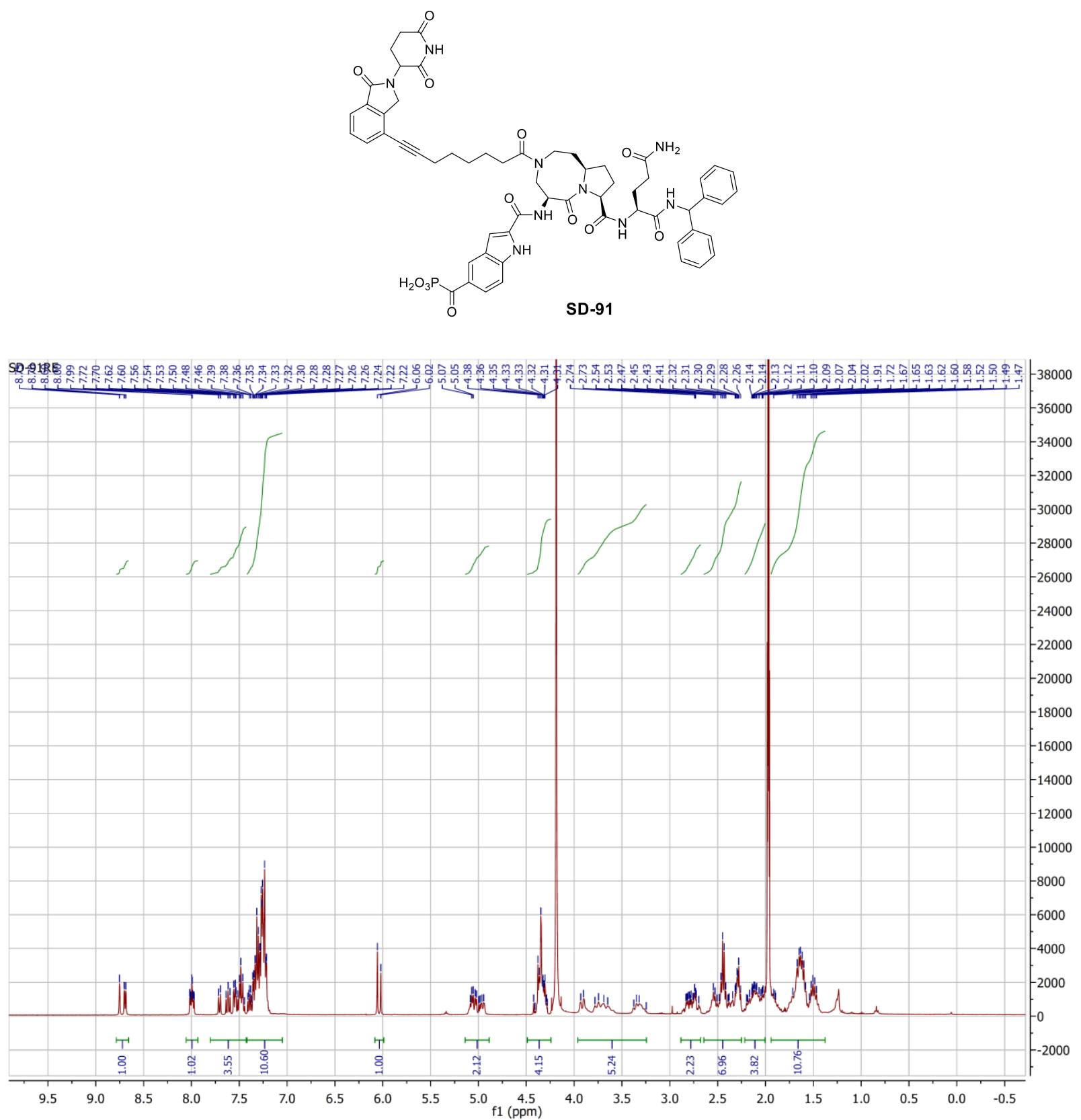
${ }^{1} \mathrm{H}$ NMR for compound SD-91 (DMSO-d6).
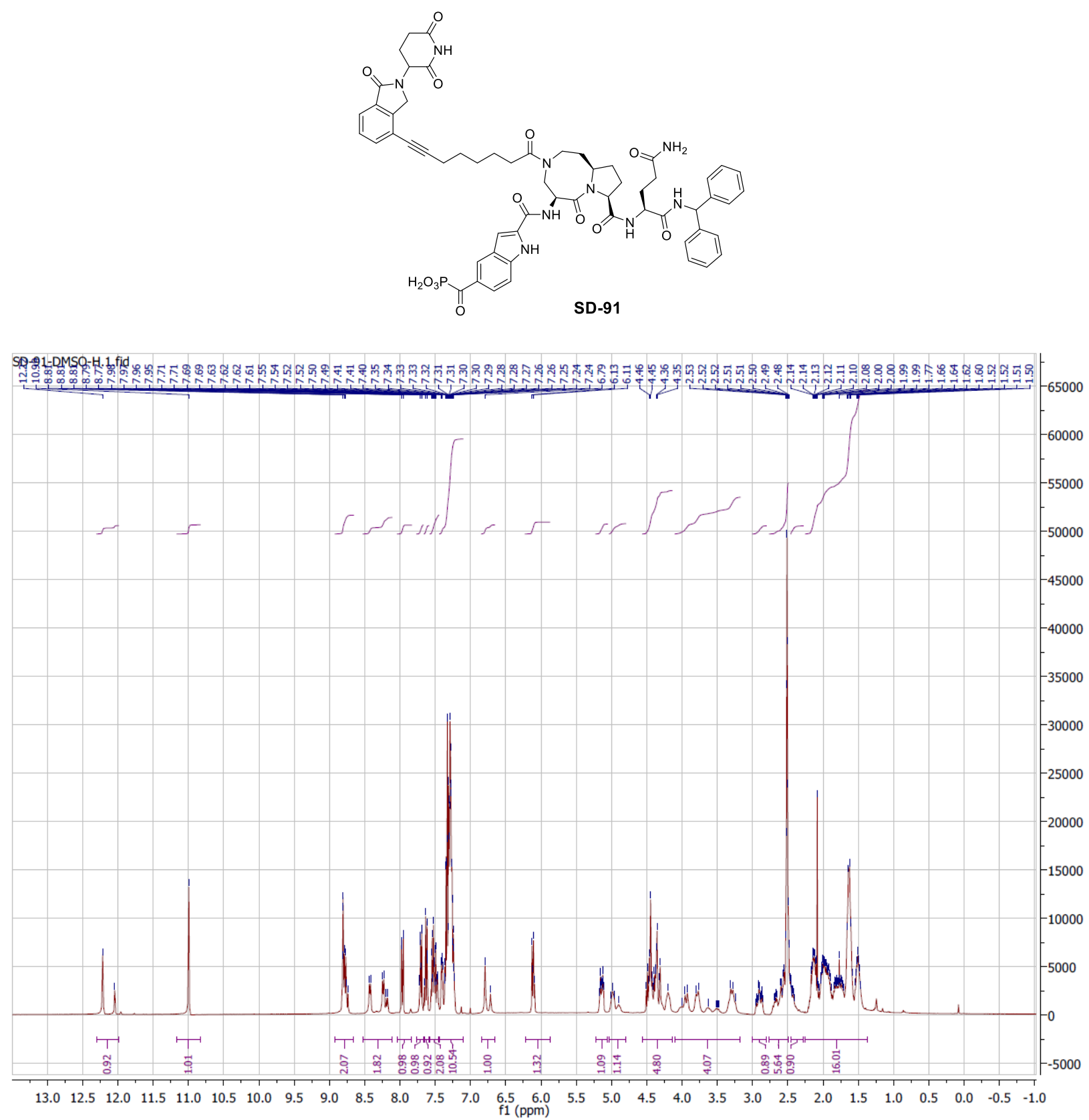


\section{UPLC-MS analysis for SD-91.}

\begin{tabular}{|llll|}
\hline & \multicolumn{2}{c|}{ S A M P L E } & I N F O R M A T I O N \\
\hline \hline Sample Name: & ZH-SD-91 & Acquired By: & System \\
Sample Type: & Unknown & Date Acquired: & $10 / 10 / 2020$ 10:14:01 PM EDT \\
Vial: & $1: C, 2$ & Acq. Method Set: & 10 to100\% Bin 10 min_Delay5min \\
Injection \#: & 1 & Date Processed: & $11 / 28 / 2020$ 3:35:39 PM EST \\
Injection Volume: & 6.00 ul & Processing Method: Bruce \\
Run Time: & 10.0 Minutes & Channel Name: & 254.Onm \\
Sample Set Name: & 3 & Proc. Chnl. Descr.: & PDA Spectrum PDA 254.0 nm (PDA \\
\hline
\end{tabular}

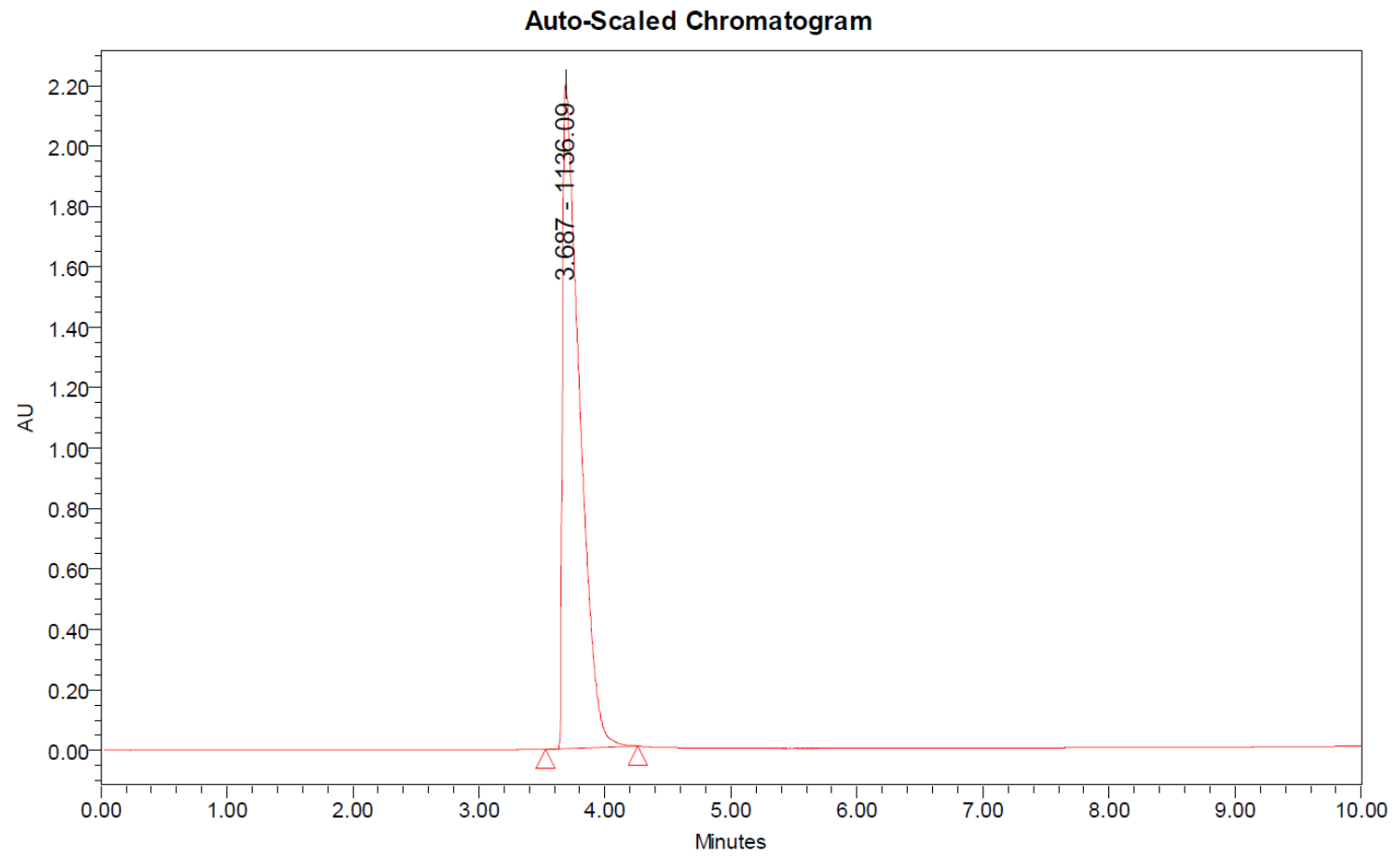

\begin{tabular}{|l|c|c|c|c|}
\multicolumn{5}{|c|}{ Peak Results } \\
\hline & RT & Area & Height & $\%$ Area \\
\hline 1 & 3.687 & 20720986 & 2200552 & 100.00 \\
\hline
\end{tabular}

Peak Results

\begin{tabular}{|c|c|}
\hline & $\begin{array}{c}\text { Base } \\
\text { Peak } \\
(\mathbf{m} / \mathbf{z})\end{array}$ \\
\hline 1 & 1136.09 \\
\hline
\end{tabular}

